\section{Ubbo Wiersema}

\section{Tissue Doppler imaging, volume responsiveness and impaired relaxation}

Accepted: 8 November 2012

Published online: 23 January 2013

(C) Springer-Verlag Berlin Heidelberg and ESICM 2013

An author's reply to this comment is available at: doi:

10.1007/s00134-013-2818-y.

Dear Editor,

Diastolic dysfunction is a common

finding in critically ill septic patients,

but the condition may respond

dynamically to changes in loading

conditions during resuscitation. In

their study of 83 mechanically venti-

lated septic patients with circulatory

failure, Mahjoub et al. [1] demon-

strated that amongst patients with left ventricular (LV) diastolic dysfunction (impaired relaxation) at baseline, volume responders $(>15 \%$ increase in LV stroke volume in response to volume expansion) showed an increase in tissue Doppler early diastolic velocity $\left(\mathrm{E}^{\prime}\right)$, whereas volume non-responders showed no increase in $\mathrm{E}^{\prime}$. The authors attributed the increased $\mathrm{E}^{\prime}$ to improved active LV relaxation from better myocardial perfusion. The authors dismiss the alternative explanation that $\mathrm{E}^{\prime}$ may be preload dependent, citing previous studies that concluded that $\mathrm{E}^{\prime}$ is less preload-dependent under conditions of impaired relaxation [2, 3]. However, there are numerous variables that can influence load dependency of tissue Doppler parameters [4].

The authors also reported that $\mathrm{E} / \mathrm{E}^{\prime}$ ratio increased significantly in volume non-responders, but not in volume responders. To explain both the $\mathrm{E}^{\prime}$ and $\mathrm{E} / \mathrm{E}^{\prime}$ ratio changes in the two groups, one needs to look more closely at the tissue Doppler features of patients with impaired relaxation.

Impaired relaxation pattern of LV diastolic dysfunction may be divided into two groups according to the $\mathrm{E} / \mathrm{E}^{\prime}$ ratio $(>15$ or $<15)$ at rest, reflecting differences in passive LV compliance. Results of a study by Choi et al. [5] showed that patients with impaired relaxation and resting $\mathrm{E} / \mathrm{E}^{\prime}$ ratio $<15$ could be further subdivided according to the $\mathrm{E} / \mathrm{E}^{\prime}$ ratio response to a virtual fluid challenge (passive leg raise). Those with persistent $\mathrm{E} / \mathrm{E}^{\prime}$ ratio $<15$ (described by Choi et al. as 'stable relaxation abnormality') showed increased $\mathrm{E}^{\prime}$ after leg raise, whereas those with an increase in $\mathrm{E} / \mathrm{E}^{\prime}$ ratio to a value $>15$ ('unstable relaxation abnormality') had minimal increase in $\mathrm{E}^{\prime}$. Incorporating these concepts into the interpretation of the study by Mahjoub et al., it may be argued that the $\mathrm{E}^{\prime}$ and $\mathrm{E} / \mathrm{E}^{\prime}$ ratio response to volume expansion differentiates a state of 'stable relaxation abnormality' from 'unstable relaxation abnormality', where there are no distinguishing features at baseline. Taken a step further, patients with 'stable relaxation abnormality' would be preload responsive and those with 'unstable relaxation abnormality' would not be preload responsive. Unfortunately, a volume challenge (real or virtual) would be required to distinguish these two subgroups, as there are no baseline differences. Furthermore, as Mahjoub et al. demonstrated, the dynamics of $\mathrm{E}^{\prime}$ and the $\mathrm{E} / \mathrm{E}^{\prime}$ ratio do not help predict volume responsiveness in those without LV diastolic dysfunction; an alternative mechanism to limit volume responsiveness must be invoked in this group.

\section{References}

1. Mahjoub Y, Bernoit-Fallet H, Airapetian N, Lorne E, Levrard M, Seydi A-A, Amennouche N, Slama M, Dupont H (2012) Improvement of left ventricular relaxation as assessed by tissue Doppler imaging in fluid-responsive critically ill septic patients. Intensive Care Med 38:1461-1470. doi: 10.1007/s00134-012-2618-9

2. Firstenberg MS, Greenberg NL, Main ML, Drinko JK, Odabashian JA, Thomas JD, Garcia MJ (2001) Determinants of diastolic myocardial tissue Doppler velocities: influences of relaxation and preload. J Appl Physiol 90:299-307

3. Nagueh SF, Sun H, Kopelen HA, Middleton KJ, Khoury DS (2001) Haemodynamic determinants of the mitral annulus diastolic velocities by tissue Doppler. J Am Coll Cardiol 37:278-285

4. Aissaoui N, Guerot E, Combes A, Delouche A, Chastre J, Leprince P, Leger P, Diehl JL, Fagon JY, Diebold B (2012) Two-dimensional strain rate and Doppler tissue myocardial velocities: analysis by echocardiography of haemodynamic and functional changes of the failed left ventricle during different degrees of extracorporeal life support. J Am Soc Echocardiogr 25:632-640

5. Choi E-Y, Shim CY, Kim S-A, Rhee SJ, Choi D, Rim S-J, Jang Y, Chung N, Cho S-Y, Ha J-W (2010) Passive leg-raise is helpful to identify impaired diastolic functional reserve during exercise in patients with abnormal myocardial relaxation. J Am Soc Echocardiogr 23:523-530

U. Wiersema (

Intensive and Critical Care Unit, Flinders Medical Centre, Flinders Drive, Bedford Park, SA 5042, Australia e-mail: ubbo.wiersema@health.sa.gov.au Tel.: +61-8-82046841

Fax: +61-8-82045751 